\title{
PENGARUH MENGIKUTI ORGAMAWA DAN REGULASI DIRI TERHADAP PROKRASTINASI MAHASISWA DALAM MENYELESAIKAN SKRIPSI DI FAKULTAS ILMU PENDIDIKAN IKIP PGRI MADIUN TAHUN AKADEMIK 2015/2016.
}

\author{
Agus Iswahyudi* \\ zugawahyu95@gmail.com \\ Ibnu Mahmudi** \\ mahmudiibnu@gmail.com
}

\begin{abstract}
Abstrak
Prokrastinasi yang dilakukan mahasiswa dalam mengerjakan skripsi dapat dipengaruhi beberapa faktor, diantaranya adalah mengikuti organisasi kemahasiswaan (Orgamawa) dan regulasi diri.Tujuan penelitian ini adalahuntuk mengetahui pengaruh mengikuti orgamawa terhadap prokrastinasi mahasiswa dalam menyelesaikan skripsi, pengaruh regulasi diri terhadap prokrastinasi mahasiswa dalam menyelesaikan skripsi, serta pengaruh mengikuti Orgamawa dan regulasi diri terhadap prokrastinasi mahasiswa dalam menyelesaikan skripsidi Fakultas Ilmu Pendidikan IKIP PGRI Madiun tahun akademik 2015/2016.

Metode penelitian yang digunakan metode kuantitatif dengan desain penelitian ex-post facto.Populasi pada penelitian seluruh mahasiswa Fakultas Ilmu Pendidikan IKIP PGRI Madiun tahun akademik 2015/2016 yang menjadi pengurus Orgamawa dan sedang menempuh program penyusunan skripsi ber jumlah 60orang. Penentuan sampel dengan teknik sampling jenuh. Data penelitian dikumpulkan menggunakan teknik angket. Analisis data dalam penelitian ini menggunakan analisis regresi dua prediktor.

Simpulan penelitian ini adalah: (1) ada pengaruh mengikuti Orgamawa terhadap prokrastinasi mahasiswa dalam menyelesaikan skripsi di Fakultas Ilmu Pendidikan IKIP PGRI Madiun tahun akademik 2015/2016, (2) ada pengaruh regulasi diri terhadap prokrastinasi mahasiswa dalam menyelesaikan skripsi di Fakultas Ilmu Pendidikan IKIP PGRI Madiun tahun akademik 2015/2016, dan (3) ada pengaruh secara simultan mengikuti Orgamawa dan regulasi diri terhadap prokrastinasi mahasiswa dalam menyelesaikan skripsi di Fakultas Ilmu Pendidikan IKIP PGRI Madiun tahun akademik 2015/2016.
\end{abstract}

Kata Kunci: Mengikuti Orgamawa, Regulasi Diri, Prokrastinasi Mahasiswa dalam Menyelesaikan Skripsi

* Agus Ihwahyudi adalah Mahasiswa Program Studi Bimbingan dan Konseling Fakultas Ilmu Pendidikan IKIP PGRI MADIUN

** Ibnu Mahmudi adalah Dosen Program Studi Bimbingan dan Konseling Fakultas Ilmu Pendidikan IKIP PGRI MADIUN 


\section{PENDAHULUAN}

Mahasiswa sebagai bagian dari institusi pendidikan tidak terlepas dari tugas yang bersifat akademik dan non akademik. Tugas-tugas akademis dapat berupa tugas perkuliahan sampai tugas akhir berupa penyusunan skripsi, sedangkan tugas non akademis merupakan salah satu penunjang bagi mahasiswa dalam menghadapi masa depan, khususnya terkait dunia kerja.Banyaknya tugas dan kegiatan yang diikuti dan dilakukan, mendorong mahasiswa untuk mampu mengatur dan mengelola waktu dengan baik agar semua kegiatankegiatan dapat berjalan dengan baik.

Realita yang ada menunjukkan bahwa tidak semua mahasiswa memiliki kemampuan mengatur waktu dengan baik.Ada mahasiswa yang suka menunda-nunda mengerjakan skripsi.Penundaan dalam menyelesaikan skripsi juga terjadi pada mahasiswa Fakultas Ilmu Pendidikan IKIP PGRI Madiun.Berdasarkan hasil wawancara dengan bagian kemahasiswaan Fakultas Ilmu Pendidikan ditemukan informasi bahwa masih banyak mahasiswa Fakultas Ilmu Pendidikan IKIP PGRI Madiun yang mengikuti Orgamawa, belum menyelesaikan tugas skripsinya dengan berbagai alasan.

Hal ini didukung dengan informasi yang diperoleh dari hasil wawancara dengan tiga mahasiswa tingkat akhir di Fakultas Ilmu Pendidikan IKIP PGRI Madiun, yang menunjukkan adanya indikasi psikologis yang dialami siswa yang melakukan penundaan selama menjalani proses penyusunan skripsi. Mahasiswa mengaku bahwa kurang memahami teori-teori keilmuan dalam disiplin ilmu masing-masing dikarenakan jarang mengikuti perkuliahan.Selain itu, ada juga mahasiswa yang mengaku minder karena merasa tidak memiliki teman seangkatan lagi di kampus. Mahasiswa yang lain juga mengaku menunda mengerjakan skripsi karena memiliki banyak aktivitas di luar akademik, seperti bekerja dan aktif mengikuti kegiatan organisasi kemahasiswaan.

Penundaan yang dilakukan mahasiswa yang menempuh skripsi dinamakan prokrastinasi akademik.Sebagaimana pernyataan yang disampaikan Steel (2007: 65) bahwa prokrastinasi adalah menunda dengan sengaja kegiatan yang diinginkan walaupun individu mengetahui bahwa perilaku penundaanya tersebut dapat menghasilkan dampak buruk.Hasil penelitian Qadariah, dkk.(2012: 125) menunjukkan bahwa "mayoritas mahasiswa yang sedang mengontrak atau menyusun skripsi memiliki prokrastinasi yang lebih tinggi dalam aspek takut gagal." Tugas yang dirasa sulit cenderung akan ditunda dan tugas yang dirasa mudah 
cenderung akan dikerjakan terlebih dahulu.

Prokrastinasi yang dilakukan mahasiswa dalam mengerjakan skripsi dapat dipengaruhi beberapa faktor, diantaranya adalah mengikuti organisasi

kemahasiswaan

(Orgamawa) dan regulasi diri.Hasil penelitian Jannah dan Muis (2014: 7) menunjukkan bahwa terdapat hubungan antara keaktifan organisasi dengan tingkat prokrastinasi akademik mahasiswa. Semakin tinggi keaktifan mengikuti organisasi maka semakin tinggi pula tingkat prokrastinasi akademik mahasiswa.

Organisasi mahasiswa

(orgamawa) merupakan wadah pengembangan kegiatan ekstrakurikuler mahasiswa di perguruan tinggi.Data dokumen kegiatan mahasiswa menunjukkan bahwa Orgamawa yang ada di IKIP PGRI Madiun meliputi Badan Eksekutif Mahasiswa (BEM), Unit Kegiatan Mahasiswa (UKM), Himpunan Mahasiswa Fakultas (HMF), dan Himpunan Mahasiswa Program Studi (HMPS). Kesibukan mahasiswa dalam mengikuti kegiatan Orgamawa dapat menyebabkan kelelahan serta ketidakmampuan mahasiswa dalam mengatur waktu, khususnya dalam rangka menyelesaikan skripsi.

Faktor lain yang diduga menyebabkan mahasiswa menundanunda penyelesaian skripsi adalah regulasi diri yang dimiliki mahasiswa. Hal ini relevan dengan temuan penelitian Hendrianur (2015: 539) yang menunjukkan bahwa terdapat hubungan yang signifikan antara regulasi diri dengan prokrastinasi dalam menyelesaikan skripsi pada mahasiswa.Semakin tinggi regulasi diri yang dimiliki mahasiswa, maka tingkat prokrastinasinya semakin rendah.

Berdasarkan hal tersebut maka peneliti tertarik untuk mengadakan penelitian tentang: "Pengaruh Mengikuti Orgamawa dan Regulasi Diri terhadap Prokrastinasi Mahasiswa dalam Menyelesaikan Skripsi di Fakultas Ilmu Pendidikan IKIP PGRI Madiun Tahun Akademik 2015/2016."Adapun tujuan penelitian ini adalah untuk mengetahui: (1) pengaruh mengikuti Orgamawa terhadap prokrastinasi mahasiswa dalam menyelesaikan skripsidi Fakultas Ilmu Pendidikan IKIP PGRI Madiun tahun akademik 2015/2016, (2) pengaruh regulasi diri terhadap prokrastinasi mahasiswa dalam menyelesaikan skripsidi Fakultas Ilmu Pendidikan IKIP PGRI Madiun tahun akademik 2015/2016, dan (3) pengaruh mengikuti Orgamawa dan regulasi diri terhadap prokrastinasi mahasiswa dalam menyelesaikan skripsidi Fakultas Ilmu Pendidikan IKIP PGRI Madiun tahun akademik 2015/2016.

$$
\text { Rivai (2011: }
$$

mengemukakan bahwa organisasi adalah suatu bentuk kelompok indidu-individu dengan struktur dan 
tujuan tertentu.Sudarman (2004: 34) menjelaskan tentang organisasi yang diikuti oleh mahasiswa atau yang biasa disebut dengan Orgamawa atau organisasi kemahasiswaan, dikemukakan bahwa pada dasarnya, orgamawa di suatu perguruan tinggi, diselenggarakan atas dasar prinsip dari, oleh dan untuk mahasiswa itu sendiri. Orgamawa juga sebagai wadah pengembangan kegiatan ekstrakurikuler mahasiswa di perguruan tinggi yang meliputi pengembangan penalaran, keilmuan, minat, bakat dan kegemaran mahasiswa itu sendiri.

Organisasi kemahasiswaan di Perguruan Tinggi dipayungi oleh SK Menteri Pendidikan dan Kebudayaan Republik Indonesia Nomor 155/U/1998. Pasal 1 ayat 1 surat keputusan tersebut menyatakan bahwa organisasi kemahasiswaan intra perguruan tinggi adalah wahana dan sarana pengembangan diri mahasiswa ke arah perluasan wawasan dan peningkatan kecendekiawanan serta integritas kepribadian untuk mencapai tujuan pendidikan tinggi. Pada ayat 3 menyebutkan organisasi kemahasiswaan antar perguruan tinggi adalah wahana dan sarana pengembangan diri mahasiswa untuk menanamkan sikap ilmiah, pemahaman tentang arah profesi dan sekaligus meningkatkan kerjasama, serta menumbuhkan rasa persatuan dan kesatuan.
Menurut pasal 5 SK Menteri Pendidikan dan Kebudayaan Republik Indonesia Nomor 155/U/1998, organisasi kemahasiswaan intra perguruan tinggi mempunyai manfaat sebagai sarana dan wadah: (a) Perwakilan mahasiswa tingkat perguruan tinggi untuk menampung dan menyalurkan aspirasi mahasiswa, menetapkan garis-garis besar program dan kegiatan kemahasiswaan.

Pelaksanaan kegiatan kemahasiswaan. (3) Komunikasi antar mahasiswa. (4) Pengembangan potensi jatidiri mahasiswa sebagai insan akademis, calon ilmuwan dan intelektual yang berguna di masa depan. (5) Pengembangan pelatihan keterampilan organisasi, manajemen dan kepemimpinan mahasiswa. (6) Pembinaan dan pengembangan kader-kader bangsa yang berpotensi dalam melanjutkan kesinambungan pembangunan nasional. (7) Untuk memelihara dan mengembangkan ilmu dan teknologi yang dilandasi oleh norma-norma agama, akademis, etika, moral, dan wawasan kebangsaan.

Organisasi ekstrakurikuler adalah kegiatan yang tidak wajib diikuti oleh mahasiswa selama studinya sehingga melengkapi hasil belajar secara utuh. Menurut Sukirman (2004: 69) dengan mengikuti organisasi ekstrakurikuler akan memperoleh manfaat sebagai berikut: melatih kerjasama dalam bentuk tim kerja multi disiplin, 
membina sikap mandiri, percaya diri, disiplin dan bertanggung jawab, melatih berorganisasi, melatih berkomunikasi dan menyatakan pendapat di muka umum, membina dan mengembangkan minat bakat, menambah wawasan, meningkatkan rasa kepedulian dan kepekaan pada masyarakat dan lingkungan mahasiswa, serta membina kemampuan kritis, produktif dan inovatif.

Urip Santoso (2014: 1) menyatakan berorganiasi bagi mahasiswa sangat penting dan memiliki banyak manfaat diantaranya yaitu: memperluas pergaulan, melatih kepekaan sosial, membentuk pola pikir yang lebih baik, menjadi kuat dalam menghadapi tekanan, meningkatkan kemampuan komunikasi, melatih leadership/kepemimpinan,

memperluas jaringan, mengasah kemampuan sosial, belajar mengatur waktu, ajang latihan dunia kerja yang sesungguhnya, serta meningkatan wawasan dan pengetahuan.

Mengikuti organisasi kemahasiswaan adalah perilaku mahasiswa untuk mengikuti kegiatan organisasi

kemahasiswaan.Berdasarkan alasanalasan atau manfaat mengikuti orgamawa yang diuraikan menurut beberapa ahli di atas, dalam penelitian ini disampaikan indikatorindikator dari mengikuti organisasi mahasiswa (Orgamawa), yaitu: (1) melatih kerjasama, (2) membina sikap mandiri, percaya diri, disiplin dan bertanggung jawab, (3) melatih berkomunikasi dan berpendapat di muka umum, (4) melatih leadership/kepemimpinan, serta (5) meningkatan pergaulan, wawasan dan pengetahuan.

Regulasi diri (self regulation)mengacu pada cara orang mengontrol dan mengarahkan tindakan sendiri (Taylor, dkk., 2009: 133). Sejalan dengan hal tersebut, Zimmerman dan Schunk (dalam Schunk, 2012: 35) menyatakan bahwa regulasi diri mengacu pada proses dimana individu secara sistematis mengarahkan pikiranpikiran, perasaan-perasaan, dan tindakan-tindakan kepada pencapaian tujuan.

Taylor, dkk. (2009: 134) menyatakan bahwa untuk memahami regulasi diri,ada lima aspek yang perlu diperhatikan, yaitu: (1) Konsep Diri yang Bekerja. Konsep diri yang bekerja disini maksudnya adalah konsep diri individuyang sedang ditonjolkan relevan atau sejalan dengan situasi tertentu.

Kompleksitas Diri. Beberapa orang memandang diri mereka dengan satu atau dua cara yangmendominasi, sedangkan yang lainya melihat diri mereka berdasarkan berbagai macam kualitas. (3)Kecakapan Diri dan Kontrol Personal.Pengalaman keberhasilan dankesuksesan akan menyebabkan orangmengembangkan konsep yang cukup stabiltentang kecakapan dirinya dalam domain 
kehidupan yang berbeda-beda. (4) Aktivasi dan Penghindaran Behavioral. Regulasi diri melibatkan keputusan fundamental tentang aktivitas apayang akan dilakukan dan apa yang mesti dihindari. (5) Kesadaran Diri. Seseorang juga mulai memikirkan dirinya bukan sebagai aktordilingkungan, namun sebagai objek perhatian orang lain. Secara umum, kesadarandiri menyebabkan orang mengevaluasi perilakunya berdasarkan standard danmelakukan proses penyesuaian untuk memenuhi standar.

Schunk

(2012:

menyebutkan ada tiga sub proses dari regulasi diri, yaitu: (1) Pemantauan Diri (self-monitoring); pemantauan diri mengacu pada penekanan perhatian pada beberapaaspek perilaku seseorang dan sering dipadukan dengan pencatatan frekuensi dan intensitasnya. Pemantauan terhadap diri sendirimembuat individu sadar dengan perilaku yang ada dan membantu merekamengevaluasi dan memperbaiki perilaku tersebut.(2) Pengajaran Diri (self-intruction); pengajaran diri mengacu pada pembuatan stimulus pembeda yangmengatur kemunculan respon pengaturan diri yang membawa pada pelaksanaan. Dalam hal ini pengajaran diri tidak samadengan pelatihan pengajaran diri. (3) Pendesak Diri (self-reinforcement); pendesak diri mengacu pada proses dimana seseorang memaksa dirinyatergantung pada kinerja respon yang diinginkan, yang meningkatkankecenderungan pada respon di masa mendatang.

Zimmerman (dalam Ormrod, 2008: 30) mengungkapkan bahwa individu yang memiliki kemampuan self-regulation yaitu individu yang memilikiaspek dari selfregulationberikut ini: (1) Standar dan Tujuan yang Ditetapkan Sendiri; individu cenderung memilikistandarstandar yang umum bagi perilaku kita, standar yang menjadi kriteriauntuk mengevaluasi performa kita dalam situasi-situasi spesifik. Individu jugamembuat tujuan-tujuan tertentu yang kita anggap bernilai dan yang menjadi arahdan sasaran perilaku kita.Memenuhi standarstandar dan tujuan memberi kepuasan (self-satisfaction), meningkatkan self-efficacy kita,memacu untuk meraih yang lebih besar lagi.(2) Memonitor Diri (Self-monitoring); memonitor diri adalah mengamati diri sendiri saat sedang

melakukansesuatu.Pemantauan diri (self-monitoring) mengacu pada penekanan perhatian padabeberapa aspek perilaku seseorang dan sering dipadukan dengan pencatatanfrekuensi atau intensitasnya.(3) Evaluasi Diri; evaluasi diri adalah penilaian terhadap performa atau perilaku sendiri.Evaluasi diri terdiri dari penilaian diri atas kinerja terkini dengan membandingkantujuan 
seseorang dan reaksi diri pada penilaian tersebut denganmempertimbangkan kinerja yang tercatat, yang tidak diterima, dan sebagainya. (4) Konsekuensi yang Ditetapkan Sendiri atas Kesuksesan atau Kegagalan; konsekuensi adalah individu bisa memberikan penguatanataupun hukuman atas perilaku yang mereka lakukan. Individu bisa memberikanpenguatan pada diri mereka ketika berhasil menyelesaikan tujuan-tujuan mereka.Individu juga bisa membuat konsekuensi hukuman pada dirinua,ketika melakukan sesuatu yang tidak memenuhi standar performanya.

Berdasarkan uraian aspek-aspek regulasi diri di atas, dalam penelitian ini disampaikan indikator-indikator dari regulasi diri, yaitu: pengaturan konsep diri, pemantauan terhadap diri sendiri untuk mengevaluasi dan memperbaiki perilaku, pengajaran untuk pengaturan diri, kecakapan diri untuk kontrol personal, dan keputusan terhadap aktivitas apa yang harus dilakukan dan yang harus dihindari.

Menurut Mutaqin (2015: 1) skripsi merupakan kegiatan hasil penelitian ilmiah.Dikatakan ilmiah karena skripsi diwajibkan mengikuti prosedur ilmiah yang telah menjadi ketentuan ilmiah.Skripsi adalah karya ilmiah yang wajib ditulis oleh mahasiswa sebagai tugas akhir untuk memenuhi salah satu persyaratan menyelesaikan program strata 1 dengan bobot 6 sks (IKIP PGRI Madiun, 2016: 2).

Burka dan Yuen (dalam Ghufron dan Risnawita, 2011: 150) Istilah prokrastinasi berasal dari bahasa Latin procrastination dengan awalan "pro" yang berarti mendorong maju atau bergerak maju dan akhiran "crastinus" yang berarti keputusan esok, atau jika digabungkan menjadi menangguhkan atau menunda sampai hari berikutnya.Steel (2007: 65) menyatakan bahwa prokrastinasi adalah menunda dengan sengaja kegiatan yang diinginkan walaupun individu mengetahui bahwa perilaku penundaanya tersebut dapat menghasilkan dampak buruk. Steel juga menyatakan bahwa prokrastinasi adalah suatu penundaan sukarela yang dilakukan oleh individu terhadap tugas/pekerjaannya meskipun ia tahu bahwa hal ini akan berdampak buruk pada masa depan.

Menurut Ferrari (dalam Ghufron dan Risnawita, 2011: 158-159), mengatakan bahwa sebagai suatu perilaku penundaan, prokrastinasi akademik dapat terminifestasikan dalam indikator tertentu yang dapat diukur dan diamati dalam ciri-ciri tertentu berupa: (1) Penundaan untuk memulai maupun menyelesaikan kerja pada tugas yang dihadapi; penundaan untuk memulai maupun menyelesaikan kerja pada tugas yang dihadapi jadi siswa yang melakukan prokrastinasi tahu bahwa tugas yang dihadapinya harus segera 
diselesaikan, akan tetapi dia menunda-nunda untuk mulai mengerjakannya atau menundanunda untuk menyelesaikan sampai tuntas jika dia sudah mulai mengerjakan sebelumnya.

Keterlambatan dalam mengerjakan tugas; keterlambatan dalam mengerjakan tugas, jadi siswa yang melakukan prokrastinasi memerlukan waktu yang lebih lama daripada waktu yang dibutuhkan pada umumnya dalam mengerjakan suatu tugas. Seorang prokrastinator menghabiskan waktu yang dimilikinya untuk mempersiapkan diri secara berlebihan, maupun melakukan hal-hal yang tidak dibutuhkan dalam penyelesaian suatu tugas, tanpa memperhitungkan keterbatasan waktu yang dimilikinya. (3) Kesenjangan waktu antara rencana dan kinerja aktual; individu yang melakukan prokrastinasi mempunyai kesulitan untuk melakukan sesuatu sesuai dengan batas waktu yang telah ditentukan sebelumnya. Seseorang mungkin telah merencanakan untuk mulai mengerjakan tugas pada waktu yang telah ditentukan akan tetapi ketika saatnya tiba tidak juga melakukannya sesuai dengan apa yang telah direncanakan, sehingga menyebabkan keterlambatan maupun kegagalan untuk menyelesaikan tugas secara memadai dengan melakukan aktivitas lain yang lebih menyenangkan dari pada melakukan tugas yang harusnya dikerjakan. (4)
Melakukan aktivitas yang lebih menyenangkan; melakukan aktivitas yang lebih menyenangkan daripada melakukan tugas yang harus dikerjakan. Seseorang yang melakukan prokrastinasi dengan sengaja tidak segera melakukan tugasnya, akan tetapi menggunakan waktu yang dimiliki untuk melakukan aktivitas lain yang dipandang lebih menyenangkan dan mendatangkan hiburan, seperti membaca (koran, majalah, atau buku cerita lainnya), nonton, ngobrol, jalan, mendengarkan musik, dan sebagainya, sehingga menyita waktu yang dimiliki untuk mengerjakan tugas yang harus diselesaikannya.

Burka dan Yuen (2008: 8), menjelaskan ciri-ciri seorang pelaku prokrastinasi antara lain: prokrastinator lebih suka untuk menunda pekerjaan atau tugastugasnya, berpendapat lebih baik mengerjakan nanti dari pada sekarang, dan menunda pekerjaan adalah bukan suatu masalah, terus mengulang perilaku prokrastinasi, pelaku prokrastinasi akan kesulitan dalam mengambil keputusan.

Berkaitan uraian tentang prokrastinasi akademik di atas, dalam penelitian ini dapat ditentukan beberapa indikator pemahaman tentang prokrastinasi akademik sebagai berikut: penundaan untuk memulai dan menyelesaikan skripsi, keterlambatan dalam mengerjakan skripsi, kesenjangan waktu antara rencana dan kinerja aktual, dan 
melakukan aktivitas yang lebih menyenangkan.

\section{METODE PENELITIAN}

\section{Desain Penelitian}

Desain penelitian menggunakan desain deskriptif korelasional ex post facto. Penggunaan metode ex post facto ini sejalan dengan pendapat Nazir (2005: 73) yang menyatakan bahwa penelitian expost facto adalah penyelidikan secara empiris yang sistematik, dimana peneliti tidak mempunyai kontrol langsung terhadap variabel-variabel bebas (independent variables) karena manifestasi fenomena telah terjadi atau karena fenomena sukar dimanipulasikan.

\section{Populasi, Sampel, dan Teknik Pengambilan Sampel}

Populasi yang menjadi sasaran penelitian ini adalah seluruh mahasiswa Fakultas Ilmu Pendidikan IKIP PGRI Madiun tahun akademik 2015/2016 yang mengikuti Orgamawa dan sedang menempuh program penyusunan skripsi. Berdasarkan data yang ada pada bagian akademik di Fakultas Ilmu Pendidikan IKIP PGRI Madiun, diketahui bahwa jumlah mahasiswa yang mengikuti Orgamawa dan menempuh program penyusunan skripsi adalah sebanyak 60 orang.Teknik pengambilan sampel yang digunakan dalam penelitian ini adalah teknik sampling jenuh. Menurut Sugiyono (2010: 124-125) sampling jenuh adalah teknik penentuan sampel bila semua anggota populasi digunakan sebagai sampel. Hal ini sering dilakukan bila jumlah populasi relatif kecil, kurang dari 100 orang.Dengan demikian sampel dalam penelitian ini berjumlah 60mahasiswa.

\section{Teknik Pengumpulan Data}

Data dalam penelitian ini dikumpulkan dengan menggunakan teknik angket. Angket disusun oleh peneliti dengan empat jawaban alternatif, yaitu: Selalu, Sering, Kadang-kadang, dan Tidak Pernah. Salah satu hal penting dalam penelitian adalah cara memperoleh data yang akurat dan obyektif. Hal ini menjadi sangat penting sebab kesimpulan yang diambil hanya akan dapat dipercaya bila didasarkan pada data yang akurat. Untuk itu dalam penelitian ini perlu diketahui seberapa tinggi reliabilitas dan validitas alat ukur (instrumen) yang digunakan.

Pada penelitian ini, uji validitas dan reliabilitas angket dilakukan dengan menyebarkan angket ke sampel uji coba sebanyak 20 orang mahasiswa di luar mahasiswaFakultas Ilmu Pendidikan IKIP PGRI Madiun tahun akademik 2015/2016 yang mengikuti Orgamawa dan sedang menempuh program penyusunan skripsi atau yang bukan menjadi sampel penelitian. Uji validitas menggunakan analisis korelasi 
product moment dengan formulasi

sebagai berikut:

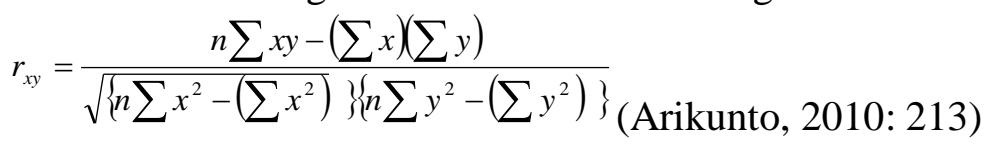

Keterangan:

$$
\begin{array}{ll}
\mathrm{r}_{\mathrm{xy}} & =\text { koefisien korelasi } \mathrm{X} \text { dan } \mathrm{Y} \\
\mathrm{n} & =\text { jumlah sampel } \\
\sum \mathrm{XY} & =\text { jumlah produk } \mathrm{X} \text { dan } \mathrm{Y} \\
\sum \mathrm{X} & =\text { jumlah nilai } \mathrm{X} \\
\sum \mathrm{Y} & =\text { jumlah nilai } \mathrm{Y}
\end{array}
$$

Dari jawaban angket sampel uji coba selanjutnya dilakukan perhitungan uji korelasi product moment dan perhitungan uji reliabilitas dengan uji cronbach alpha. Nilai $\mathrm{r}$ hitung dibandingkan dengan nilai $r$ tabel.Jika nilai $r$ hitung $<\mathrm{r}$ tabel, maka dapat dikatakan tidak valid, jika $r$ hitung > $r$ tabel, maka dikatakan valid. Berdasarkan nilai $r$ hitung yang diperoleh, dapat diketahui bahwa keseluruhan butir pernyataan untuk variabel mengikuti Orgamawa, regulasi diri, dan prokrastinasi mahasiswa dalam menyelesaikan skripsi memiliki nilai $\mathrm{r}_{\text {hitung }}$ yang lebih besar daripada nilai $\mathrm{r}_{\text {tabel }}(0,444)$. Dari hasil uji validitas, semua item angket dinyatakan valid dengan criteria/interpretasi cukup sampai sangat tinggi. Angket yang valid dapat digunakan sebagai instrument dalam pengumpulan data.

Uji reliabilitas dilakukan dengan koefisien Cronbach Alpha. Koefisien alpha ini berkisar antara 0 sampai dengan 1, jika alpha kurang dari 0,6 menunjukkan bahwa item pengukuran tidak reliabel (Ghozali, 2006: 42). Untuk menguji reliabilitas, menurut Arikunto (2010: 239) dapat dihitung dengan rumus Alpha sebagai berikut:

$$
\mathrm{R}_{1}=\left[\frac{k}{k-1}\right]\left[1-\frac{\sum \sigma_{b}^{2}}{\sigma_{t}^{2}}\right]
$$

Keterangan:

$$
\begin{aligned}
\mathrm{R}_{1} & =\text { reliabilitas instrumen } \\
\mathrm{k} & =\text { banyaknya butir pertanyaan } \\
\sigma_{b}^{2} & =\text { jumlah varian butir } \\
\sigma_{t}^{2} & =\text { jumlah varian butir angket. }
\end{aligned}
$$

Hasil uji reliabilitas angket mengikuti Orgamawa diperoleh nilai koefisien alpha $(\alpha)$, yaitu sebesar 0,949 , regulasi diri diperoleh nilai 
koefisien alpha $(\alpha)$, yaitu sebesar 0,932, dan prokrastinasi mahasiswa dalam menyelesaikan skripsi diperoleh nilai koefisien alpha $(\alpha)$, yaitu sebesar 0,926 . Nilai $r_{11}$ ketiga variabel di atas menunjukkan lebih dari 0,60. Dengan demikian dapat dinyatakan bahwa instrumen masingmasing variabel adalah reliabel.

\section{Teknik Analisis Data}

Pada penelitian ini, untuk menganalisis pengaruh mengikuti Orgamawa dan regulasi diri terhadap prokrastinasi mahasiswa dalam menyelesaikan skripsidi Fakultas Ilmu Pendidikan IKIP PGRI Madiun tahun akademik 2015/2016 menggunakan analisis regresi linier dua prediktor. Rumus analisis regresi linier dua-prediktor atau regresi linier berganda dalam penelitian ini adalah sebagai berikut:

$$
R_{x_{1}, x_{2}, y}=\sqrt{\frac{b_{1} \sum x_{1} y+b_{2} \sum x_{2} y}{\sum y^{2}}}
$$

Untuk menguji keberartian digunakan uji $F$ dengan rumus koefesien regresi secara keseluruhan Riduwan dan Sunarto (2011: 110):

$$
F_{\text {hitung }}=\frac{R^{2}(n-m-1)}{m\left(1-R^{2}\right)}
$$

\section{HASIL PENELITIAN}

Uji hipotesis yang digunakan pada penelitian ini adalah uji $\mathrm{r}$ dan uji F. Berdasarkan hasil analisis data mengenai pengaruh mengikuti Orgamawa terhadap prokrastinasi mahasiswa dalam menyelesaikan skripsi, diperoleh nilair hitung $=0,345$. Setelah dikonsultasikan dengan $r_{\text {tabel }}$ untuk $\mathrm{N}=60, \mathrm{db}=\mathrm{N}-1=59$ dan taraf signifikansi $(\alpha=5 \%)$ adalah 0,254 , sehingga dapat diketahui bahwar $r_{\text {hitung }}>r_{\text {tabel }}=(0,345>0,254)$, berarti hipotesis diterima. Artinya, ada pengaruh mengikuti Orgamawa terhadap prokrastinasi mahasiswa dalam menyelesaikan di Fakultas Ilmu Pendidikan IKIP PGRI Madiun tahun akademik 2015/2016.

Berdasarkan hasil analisis data mengenai pengaruh regulasi diri terhadap prokrastinasi mahasiswa dalam menyelesaikan skripsi,diperoleh nilai $\mathbf{r}_{\text {hitung }}=-0,316$. Setelah dikonsultasikan dengan $r_{\text {tabel }}$ untuk $\mathrm{N}=60, \mathrm{db}=\mathrm{N}-1=59$ dan taraf signifikansi $(\alpha=5 \%)$ adalah 0,254 , sehingga $r_{\text {hitung }}>r_{\text {tabel }}=(0,316$ $>0,254)$, berarti hipotesis diterima. Artinya, ada pengaruh regulasi diri 
terhadap prokrastinasi dalam menyelesaikan skripsi pada mahasiswa di Fakultas Ilmu Pendidikan IKIP PGRI Madiun tahun akademik 2015/2016.

Hasil analisis data tentang pengaruh mengikuti Orgamawa dan regulasi diri terhadap prokrastinasi mahasiswa dalam menyelesaikan skripsi dengan menggunakan Analisis Regresi Dua Prediktor diperoleh harga $F_{\text {hitung }}=7,246$. Setelah dikonsultasikan dengan harga $\mathrm{F}_{\text {tabel }}$ untuk $\mathrm{N}=60$, dengan taraf signifikan sebesar 5\% adalah 3,20 sehingga diperoleh nilai $F_{\text {hitung }}>$ $F_{\text {tabel }}$ atau $(7,246>3,20)$, berarti hipotesis diterima. Artinya, ada pengaruh secara simultan mengikuti Orgamawa dan regulasi diri terhadap prokrastinasi mahasiswa dalam menyelesaikan skripsi di Fakultas Ilmu Pendidikan IKIP PGRI Madiun tahun akademik 2015/2016.

Berdasarkan hasil analisis data diketahui bahwa hipotesis pertama yang berbunyi: "Ada pengaruh mengikuti Orgamawa terhadap prokrastinasi mahasiswa dalam menyelesaikan skripsi di Fakultas Ilmu Pendidikan IKIP PGRI Madiun tahun akademik 2015/2016" terbukti.Hasil penelitian ini relevan dengan temuan penelitian Jannah dan Muis (2014: 7) bahwa terdapat hubungan antara keaktifan organisasi dengan tingkat prokrastinasi akademik mahasiswa.Semakin tinggi mengikuti keaktifan organisasi maka semakin tinggi pula tingkat prokrastinasi akademik mahasiswa. Orgamawa yang ada di IKIP PGRI Madiun meliputi Badan Eksekutif Mahasiswa (BEM), Unit Kegiatan Mahasiswa (UKM), Himpunan Mahasiswa Fakultas (HMF), dan Himpunan Mahasiswa Program Studi (HMPS). Kesibukan mahasiswa dalam mengikuti kegiatan Orgamawa dapat menyebabkan kelelahan serta ketidakmampuan mahasiswa dalam mengatur waktu, khususnya dalam rangka menyelesaikan skripsi.Prokrastinasi mahasiswa Fakultas Ilmu Pendidikan IKIP PGRI Madiun dalam menyelesaikan skripsi disebabkan karena mahasiswa kurang memahami teori-teori keilmuan dalam disiplin ilmu masing-masing dikarenakan jarang mengikuti perkuliahan.Selain itu, mahasiswa menunda mengerjakan skripsi karena memiliki banyak aktivitas di luar akademik, seperti bekerja dan aktif mengikuti kegiatan organisasi kemahasiswaan.

Berdasarkan hasil analisis data diketahui bahwa regulasi diri berpengaruh negatif dan signifikan terhadap prokrastinasi mahasiswa dalam menyelesaikan skripsi di Fakultas Ilmu Pendidikan IKIP PGRI Madiun tahun akademik 2015/2016. Artinya, jika regulasi diri mahasiswa tinggi maka akan menurunkan prokrastinasi mahasiswa dalam menyelesaikan skripsi dan sebaliknya, jika regulasi diri mahasiswa rendah, menyebabkan prokrastinasi mahasiswa dalam 
menyelesaikan skripsi cenderung meningkat atau tinggi. Hal ini relevan dengan temuan penelitian Hendrianur (2015: 539) yang menunjukkan bahwa terdapat hubungan yang signifikan antara regulasi diri dengan prokrastinasi dalam menyelesaikan skripsi pada mahasiswa.Semakin tinggi regulasi diri yang dimiliki mahasiswa, maka tingkat prokrastinasinya semakin rendah.Prokrastinasi mahasiswa dalam mengerjakan skripsi juga disebabkan karena mahasiswa kurang memperhatikan perilaku dan kedisiplinan sehingga melupakan rencana penyelesaian skripsi yang telah disusun. Mahasiswa juga lebih banyak mengikuti kebiasaan teman daripada menentukan sendiri setiap aktivitas yang akan dilakukannya sehingga baru mengerjakan tugas penyusunan skripsi jika sudah ditegur orang tua.

Berdasarkan hasil analisis data diketahui bahwa mengikuti Orgamawa dan regulasi diri secara simultan berpengaruh positif dan signifikan terhadap prokrastinasi mahasiswa dalam menyelesaikan skripsi di Fakultas Ilmu Pendidikan IKIP PGRI Madiun tahun akademik 2015/2016.Mahasiswa merasa bahwa kesibukannya dalam kegiatan Orgamawa telah mengganggu waktu untuk mengerjakan skripsi. Pada beberapa mahasiswa yang lain menyatakan bahwa dirinya keberatan jika harus mengesampingkan pertemuan dalam organisasi yang diikutinya demi segera mengelesaikan skripsi. Berkaitan dengan regulasi diri, mahasiswa yang melakukan prokrastinasi dalam mengerjakan skripsi disebabkan karena orang tuanya tidak mempersoalkan masa studi, sehingga mahasiswa beranggapan tidak harus segera mengerjakan skripsi. Jika banyak mendapat revisi dari dosen pembimbing, mahasiswa malas melanjutkan skripsi dan memilih bermain game online atau aktivitas menyenangkan lainnya dengan teman. Saat libur, mahasiswa tergoda untuk jalan bareng atau nongkrong dengan teman.Semakin mendekati deadline, membuat mahasiswa stress dan semakin tidak fokus dalam menyusun skripsi.

\section{PENUTUP}

\section{Simpulan}

Berdasarkan hasil analisis data, dalam penelitian ini dapat disimpulkan bahwa:

a. Ada pengaruh mengikuti Orgamawa terhadap prokrastinasi mahasiswa dalam menyelesaikan skripsi di Fakultas Ilmu Pendidikan IKIP PGRI Madiun tahun akademik 2015/2016.

b. Ada pengaruh regulasi diri terhadap prokrastinasi mahasiswa dalam menyelesaikan skripsi di Fakultas Ilmu Pendidikan IKIP PGRI Madiun tahun akademik 2015/2016. 
c. Ada pengaruh secara simultan mengikuti Orgamawa dan regulasi diri terhadap prokrastinasi mahasiswa dalam menyelesaikan skripsi di Fakultas Ilmu Pendidikan IKIP PGRI Madiun tahun akademik 2015/2016.

\section{Saran}

Berdasarkan hasil pembahasan dan beberapa simpulan yang dicapai dalam penelitian ini, dapat disampaikan beberapa saran sebagai berikut.

a. Bagi mahasiswa

Diharapkan mahasiswa untuk lebih menambah wawasan mengenai dampak beserta cara mengatasi perilaku prokrastinasi akademik agar bisa mengurangi kebiasaan sehingga dapat mencapai prestasi akademik yang optimal.

b. Bagi konselor di kampus IKIP PGRI Madiun

Disarankan bagi pihak konselor di kampusIKIP PGRI Madiun untuk mengadakan kegiatan pembinaan, dapat berupa seminar yang berkaitan dengan pengetahuan dampak dari perilaku prokrastinasi akademik berserta cara mengatasinya. Konselor dapat bekerjasama dengan organisasi bimbingan dan konseling sebaya (bimbasi) untuk mengadakan kegiatan seminar guna mengatasi perilaku prokrastinasi akademik yang sudah menjadi kebiasaan mahasiswa.

c. Bagi dosen pembimbing skripsi

Dosen pembimbing skripsidiharapkan dapat memberikan motivasi kepada mahasiswa pada awal semester pengambilan skripsi. Hal ini perlu dilakukan karena dari hasil penelitian ini ditemukan fakta bahwa penundaan penyusunan skripsi pada mahasiswa Fakultas Ilmu Pendidikan IKIP PGRI Madiuntahun akademik 2015/2016 lebih disebabkan oleh diri mahasiswa sendiri yang tidak dapat mengatur waktu akibat keaktifan dalam mengikuti Orgamawaserta regulasi diri pada mahasiswa.

d. Bagi Pengembangan Ilmu Pengetahuan

Hasil penelitian ini diharapkan dapat digunakan untuk bahan pemikiran dan pertimbangan dalam pengembangan bimbingan dan konseling, khususnya yang berkaitan dengan upaya-upaya dalam mengatasi prokrastinasi mahasiswa dalam menyelesaikan skripsi.

\section{DAFTAR PUSTAKA}

Arikunto, Suharsimi. 2010. Prosedur Penelitian Suatu Pendekatan Praktik. Edisi Revisi. Cetakan Kedelapan. Jakarta: Penerbit Rineka Cipta. 
Burka, Jane B. and Yuen, Lenora, M. 2008. Procrastination: Why Yo Do It, What to Do About It Now, Canbride: Da Capo.

Ghozali, Imam. 2006. Aplikasi Analisis Multivariate Dengan Program SPSS. Semarang: Badan Penerbit Universitas Diponegoro.

Ghufron, M. Nur dan Risnawita, Rini. 2011. Teori-Teori Psikologi. Yogyakarta: Ar-Ruzz Media.

Hendrianur. 2015. Hubungan Dukungan Sosial dan Regulasi Diri dengan Prokrastinasi Dalam Menyelesaikan Skripsi. eJournal Psikologi. 3(2): 528-542.

IKIP PGRI Madiun. 2016. Pedoman Penulisan Skripsi. Edisi 2/2015. Madiun: IKIP PGRI Madiun.

Jannah, Miftahul dan Muis, Tamsil.2014. Prokrastinasi Akademik (Perilaku Penundaan Akademik) Mahasiswa Fakultas Ilmu Pendidikan Universitas Negeri Surabaya.Jurnal $B K$ UNESA. Vol. 04.No. 03.hal. 1-8.

Mutaqin, Dadang Zaenal. 2015. Buku Panduan Penyusunan Skripsi. Yogyakarta: Deepublish.

Nazir, Moh. 2005. Metode Penelitian. Bogor: Ghalia Indonesia.

Ormrod, Jeanne Ellis. 2008. Psikologi Pendidikan: Membantu Siswa Tumbuh dan Berkembang. Jakarta: Erlangga.

Qadariah, Siti; Sukarti Hilmi Manan; dan Dwi Prameisi Ramdhayani. 2012. Gambaran Faktor Penyebab Prokrastinasi pada
Mahasiswa Prokrastinator yang Mengontrak Skripsi.Prosiding SNaPP2012: Sosial, Ekonomi, dan Humaniora. Vol. 3.No. 1.hal. 119-126.

Riduwan dan Sunarto. 2013. Pengantar Statistika. Bandung: Alfabeta.

Rivai, $\quad$ Veithzal. 2011. Kepemimpinan dan Perilaku Organisasi. Jakarta: PT. Raja Grafindo Persada.

Schunk, Dale H. 2012. Learning Theories Teori-Terori Pembelajaran Perspektif Pendidikan Edisi Keenam. Yogyakarta: Pustaka Pelajar.

SK Menteri Pendidikan dan Kebudayaan Republik Indonesia Nomor 155/U/1998

Steel, P. 2007. The nature of procrastination: A meta analytic and theoretical review of quintessential self regulatory failure. Psychological Bulletin.133 (1): 65-94.

Sudarman, Paryati. 2004. Belajar Efektif di Perguruan Tinggi. Bandung: Simbiosa Rekatama Media.

Sugiyono. 2010. Metode Penelitian Pendekatan Kuantitatif, Kualitatif, $R$ \& D. Bandung: Alfabeta.

Sukirman, Silvia. 2004. Tuntunan Belajar di Perguruan Tinggi. Jakarta: Pelangi Cendikia.

Taylor, Shelley E., Letitia Anne Peplau, and David O. Sears. 2009. Psikologi Sosial. Edisi Kedua Belas. Alih Bahasa: Michael Adriyanto dan Savitri 
56 Jurnal Ilmiah Counsellia, Volume 6 No. 2, November 2016 : 41 - 55

Soekrisno. Jakarta: Kencana Prenada Mulia.

Urip Santosa. 2014. Manfaat Aktif dalam Organisasi Mahasiswa.Artikel. Universitas Bengkulu. 